\title{
TuRBAWI
}

Volume 4 No.1, Januari-Juni 2019

p-ISSN : 2527-4082, e-ISSN : 2622-920X

\section{Landasan Ontologi Ilmu Pengetahuan}

\section{Ontology Science}

\section{Rusli Malli}

ruslimalli187@gmail.com |Universitas Muhammadiyah Makassar

\begin{abstract}
Abstrak
Metode yang digunakan dalam penelitian ini adalah metode deskriptif kualitatif. Penelitian deskriptif merupakan penelitian yang bertujuan menggambarkan kedudukan akal dalam islam. Sedangkan sumbernya diambil dari beberapa buku-buku ilmiah yang diterbitkan dengan maksud dijadikan sumber referensi Adapun Tekhnik pengumpulan data dalam penelitian ini ialah Studi Kepustakaan, Wawancara dan Observasi. Pembahasan di dalam ontologi di mulai tanpa asumsi dasar, melainkan mengandalkan kreativitas akal yaitu inspirasi, intuisi, dan ilham. Metode abstraksi digunakan ontologi untuk mencari kejelasaan tentang dunia fakta seluruhnya sampai pada pengertian fundamental. Pengetahuan fundamental yang dihasilkan oleh ontologi dapat dijadikan dasar untuk membahas kembali asumsi dasar yang oleh ilmu pengetahuan telah dianggap mapan kebenarannya.
\end{abstract}

\section{Kata Kunci: Ontologi dan Ilmu Pengetahuan}




\begin{abstract}
The method used in this study is a qualitative descriptive method. Descriptive research is a study that aims to describe the position of reason in Islam. While the source is taken from several scientific books published with the intention of being used as a source of reference. The data collection techniques in this study are Literature Studies, Interviews and Observations. The discussion in ontology starts without basic assumptions, but relies on resourceful creativity, namely inspiration, intuition, and inspiration. Abstraction methods are used ontologies to find clarity about the world of facts all arrive at a fundamental understanding. Fundamental knowledge produced by ontology can be used as a basis for revisiting the basic assumptions that science has assumed are established.
\end{abstract}

\title{
Keywords: Ontology and Science
}

\section{PENDAHULUAN}

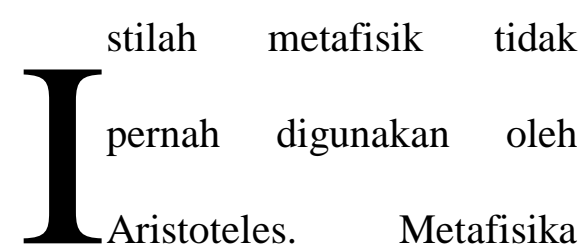

dinamakan filsafat pertama oleh

Aristoteles. Realitas, kualitas, kesempurnaan, dan yang ada merupakan filsafat pertama artinya filsafat yang bersangkutan dengan sebab terdalam dan unsur abstrak tertinggi dari segala sesuatu Karya-karya Aristoteles dikumpulkan rapi di perpustakaannya. Perpustakaan Aristoteles tersebut diwariskan kepada muridnya bernama Teofratos. Teofratos mewariskan perpustakaannya kepada Neleo. Karyakarya Aristoteles oleh raja-raja dari Pergamon dan Alexandria pernah disembunyikan. Pada tahun 100 SM buku-buku Aristoteles diketemukan oleh Appelicone dan semuanya dibawa ke Athena. Pada tahun 86 SM semua karya Aristoteles dibawa ke Roma dirawat oleh Andronikos dari Rodos. Andronikos menyusun dan mengelompokkan karya-karya Aristoteles tersebut. Andronikos mengelompokkan lebih dahulu karyakarya Aristoteles mengenai fisika. Sesudah karya-karya tentang fisika tersebut masih ada 14 buku tanpa nama 
yang kemudian karya itu disebut karya ta meta ta physica artinya karya-karya sesudah fisika. Karya-karya dalam kelompok ta meta physica tersebut membahas tentang yang ada, kesempurnaan, realitas, dan kualitas

$$
\text { Pada abad ke-17 melalui }
$$

pengaruh seorang ilmuwan bernama

Christian Wolff metafisika menjadi populer dan mulai diperhitungkan sebagai bidang keilmuan. Wolff membagi Metafisika ke dalam Metafisika umum dan Metafisika khusus. Metafisika umum juga disebut Ontologi. Metafisika khusus dibedakan 3 macam yaitu Kosmologi, PsychologiKefilsafat dan Teologi-kefilsafatan. Metafisika dikembangkan oleh Wolff lebih sebagai kajian ilmiah. Bahasan tentang yang ada sebagai yang ada diartikan prinsip umum yang dapat ditemukan pada segala sesuatu, baik yang berwujud benda mati, benda hidup, manusia maupun realitas yang tidak berwuhud (abstrak) dan yang religius.

\section{METODE PENELITIAN}

Metode yang digunakan dalam penelitian ini adalah metode deskriptif kualitatif. Penelitian deskriptif merupakan penelitian yang bertujuan menggambarkan kedudukan akal dalam islam. Sedangkan sumbernya diambil dari beberapa buku-buku ilmiah yang diterbitkan dengan maksud dijadikan sumber referensi Adapun Tekhnik pengumpulan data dalam penelitian ini ialah Studi Kepustakaan, Wawancara dan Observasi.

\section{PEMBAHASAN}

\section{A. Metafisika}

\section{Obyek Material Metafisika}

Anton Bakker

(1992)

menyebutkan objek material Metafisika adalah yang ada artinya segala-galanya. Metafisika tidak menunjuk bidang 
ekstensif atau objek material tertentu dalam penelitian, tetapi mengenai suatu inti yang termuat dalam setiap kenyataan.

Kattsoff (terj. 1986) menjelaskan bahwa yang ada merupakan predikat yang universal dalam arti merupakan peredikat dalam setiap satuan yang mungkin ada. Predikat yang ada merupakan batasan suatu himpunan yang segala sesuatu dapat termasuk di dalamnya. Baik yang nyata sebagai wujud dan abstrak maupun sesuatu yang baru terdapat dalam angan-angan (masih sebagai benih).

Lorens Bagus

(1991)

menjelaskan secara lebih ringkas bahwa yang ada meliputi semua realitas dalam semua bentuknya, baik bentuk yang indrawi maupun yang tidak indrawi.

\section{Objek Formal Metafisika}

Lorens Bagus (1991)
Metafisika adalah yang ada sebagai yang ada artinya yang ada sebagaimana adanya. Metafisika adalah bahasan tentang makna yang hakikat seluruh realitas. Metafisika membahas hal yang sangat sederhana, tetapi menjadi dasar bagi semua macam pengetahuan.

Kattsoff (terj.1986) memberikan penjelasan tentang pengertian yang ada sebagai yang ada adalah bahasan tentang hakikat realitas. Metafisika membahas hakikat realitas melalui dua macam sudut pandang. Sudut pandang yang pertama adalah pendekatan kuantitatif. Pendekatan kuantitatif membahas tentang kuantitas (jumlah) realitas yang terdalam. Permasalahannya adalah realitas terdalam tersebut tunggal atau jamak. Sudut pandang yang kedua adalah pendekataan kualitatif. Pendekatan kualitatif membahas tentang jenis realitas terdalam. Pendekatan menyebutkan bahwa objek formal kuantitatif memunculkan aliran-aliran 
menisme, paralelisme, pluralisme. pengetahuan tentang realitas akan Pendekatan kualitatif memunculkan memayungi dan menerangi pengalaman. aliran-aliran materialisme, idealisme, Refleksi Metafisik digambarkan sebagai naturalisme, dan Hylemorphisme. bentuk lingkaran hermeneutik, sehingga

\section{Metode Pada Metafisika}

Anton Bakker

(1992)

menjeleskan bahwa metode Metafisika Umum adalah suatub refleksi yang terakhir. Refleksi terakhir adalah adalah sarana metodik mengeksplisitasikan dan mentematisasikan pra pengetahuan. Pra pengetahuan adalah pengetahuan yang masih sangat umum, belum dipahami isi perinciannya, sehingga masi terbuka perkembangannya. Metafisika bergerak di antara dua kutub yaitu antara pengalaman faktawi dengan pra pengetahuan tentang yang ada. Refleksi metafisik memanfaatkan kedua kutub tersebut untuk saling menjelaskan. Pengalaman dijadikan sarana untuk semakin mengeksplisitasikan arti dan hakikat realitas. Sebaliknya pra pengalaman dan pra pengetahuan tentang realitas dalam lingkaran tersebut tidak dapat dikatakan mana yang lebih dahulu.

Lorens Bagus (1991) menunjuk metode abstraksi tingkat ketiga sebagai metode Metafisika. Abstraksi dibedakan menjadi tiga tingkatan yaitu abstraksi fisik, abstraksi bentuk (metematik) dan abstraksi metafisik. Abstraksi fisik adalah cara untuk merumuskan keseluruhan sifat-sifat khas sesuatu objek bahasan. Keseluruhan sifat-sifat khas tersebut dirumuskan dengan cara memisahkan objek bahasannya dari hubungan dengan lingkungan sekitarnya dan dari tempatnya. Suatu objek bahasan dipisahkan dari kategori relasi dan kategori tempat. Abstraksi bentuk 
(matematik) adalah cara untuk mengacu pada hal fisik atau individu merumuskan sifat-sifat umum yang tertentu. Hasil dari abstraksi metafisik menjadi ciri semua unsur individual berupa pengetahuan tentang esensi. yang tunggal jenis. Keseluruhan sifat- Pengetahuan tentang esensi yaitu sifat umum tersebut dirumuskan dengan pengetahuan tingkat ketiga adalah cara mengabaikan sifat-sifat khusus pengetahuan sesudah dan mengatasi yang individual dan hanya yang fisika.

memperhatikan sifat-sifat yang samasama dimiliki oleh seluruh objek-objek individual yang tunggal jenis. Pada abstraksi bentuk maka objek bahasan dipisahkan dari kategori kuantitas dan kategori keadaan. Hasil dari abstraksi bentuk berupa pengetahuan tentang substansi, yang bersifat abstrak dan berlaku umum universal. Abstraksi metafisik adalah cara untuk merumuskan prinsip umum yang menjadi dasar semua realitas. Prinsip umum tersebut dirumuskan dengan cara memisahkan objek bahasan dari seluruh kategori aksidensia. Pada abstraksi metafisik analisis dapat dilakukan tanpa

\section{Pembuktian Pada Metafisika}

Metafisika Mengenal dua jenis pembuktian yaitu pembuktian apriori dan aposteriori. Lorens Bagus (1991) menjelaskan secara rinci bahwa pembuktian apriori tidak dapat disamakan dengan metode deduktif. Pembuktian aposteriori tidak samah sepenuhnya dengan pembuktian dalam metode induktif. Pembiktian deduktif berdasar pada dalil-dalil umum menuju kejelasan hal-hal khusus. Pembuktian induktif berdasarkan pada hal-hal konkrit tertentu untuk merumuskan dalil umum. Pembuktian apriori dan 
aposteriori dibedakan dengan ontologis term tengah ada sesudah pembuktian deduktif dan induktif realitas kesimpulan. Term tengah berdasarkan kedudukan ontologig dari menunjukkan akibat realitas yang entitas yang ada dalam pembuktian. dinyatakan dalam kesimpulan.

Apabila dipraktekkan pada silogisme maka perbedaan antara pembuktian apriori dan aposteriori terletak pada kedudukan ontologi dari term tengah dan predikat. Pembuktian apriori berlaku apabila term tengah dalam silogisme secara ontologi berada lebih dulu dari predikat pada kesimpulan term tengah menjadi sebab bagi kebenaran kesimpulan.

Contoh :

$\checkmark$ Di mana ada sisa makanan di sana ada manusia $: \mathrm{M}-\mathrm{S}$

$\checkmark$ Sisa makanan ada di sana : $\mathrm{M}-$ $\mathrm{P}$

$\checkmark$ jadi, manusia ada di sana : S - P

Manusia ada lebih dahulu daripada sisa makanan. Manusia sebagai sebab bagi adanya sisa makanan. Pada metafisika pembuktian apriori tidak dapat dilawankan begitu saja dengan pembuktian induktif pada metafisika Contoh:

Sesuatu yang rohani adalah kekal : $\mathrm{M}-\mathrm{P}$

Jiwa adalah sesuatu yang rohani : $\mathrm{S}-\mathrm{M}$

Jadi, jiwa adalah kekal :S - P

Pada silogisme ini kerohinian menjadi sebab kebenaran tentang kekekalan jiwa. Pembuktian aposteriori yang dicari bukan dalil umum atau gejala khusus yang cocok, tetapi lebih diperhatikan titik tolaknya segi metafisik. Pada contoh silogisme dapat diketahui bahwa pembuktian aposteriori juga menumpuh jalan deduktif.

merupakan pembuktian yang secara 


\section{B. Kedudukan Objek Bahasan Ilmu Pengetahuan}

Objek penelaahan ilmu mencakup kejadiaan- kejadian atau seluruh aspek kehidupan yang dapat di uji oleh pengalaman manusia. The New Columbia Encylopedia menjelaskan bahwa. "For many the term science revere ro the organized body of knowledge concerning the physical world, both animate and inanimate". (Bagi banyak orang istilah ilmu menunjuk pada kumpulan yang teratur dari pengetahuan tentang alam kodrat, baik yang hidup maupun yang tidak hidup). Ilmu mempelajari kenyataan sebagaimana adanya yang terbatas pada lingkup pengalaman manusia. Berbagai pendapat yang berisi penjelasan mengenai hal ini dikemukan oleh The Liang Gie, yaitu:
1) Robert Lindsay dalam The Rule of science in civilization, bahwa "science is a method for the description, creation and understanding of human experience", (ilmu adalah suatu metode untuk pengambaran, penciptaan, dan pemahaman terhadap pengalaman manusia).

2) Bliss lebih menekankan bahwa ilmu tidak lepas dari data-data emperik, seperti diungkapkan dalam The Organization Knowledge.

"science is verified and organized knowledge, rationality and methodically proceeding from empirical and experimental data, simple concepts, and perceptual relation to generalization, theories,laws...”. (ilmu adalah pengetahuan yang teratur dan teruji,terproses secara metodik dan 
rasional dari data eksperimental dan bukan merupakan telaah ilmu empirik, konsep-konsep sederhana, dan pengetahuan,tetapi merupakan telaah hubungan perseptual menjadi ontologik. Aspek kedua dari landasan generalisasi-generalisasi, teori-teori, ontologi keilmuan adalah penafsiran kaidah-kaidah ...) (The Liang Gie,1984). tentang hakikat terdalam dari objek

Peryataan Bliss menujukkan

bahwa persoalan diluar pengalaman manusia bukan merupakan wilayah telaah ilmu. Ilmu pengetahuaan merupakan penjelasan rasional, tetapi harus juga berkesesuaian dengan objek yang dijelaskan. Suatu penjelasan dalam ilmu pengetahuaan bagaimana meyakinkannya harus tetap ada dukungan fakta empirik untuk dapat dinyatakan kebenarannya.

Ilmu pengetahuaan merupakan usaha manusia untuk memahami kenyataan sejauh dapat dijangkau oleh daya pemikiran manusia berdasar pengalaman manusia secara empirik. Pra pengalaman atau pasca pegalaman keilmuan. Penafsiran ontologik terhadap objek keilmuan harus didasarkan pada karakteristik objek ilmu sebagaimana adanya, terbatas dari nilai-nilai yang bersifat dogmatik. Suatu pernyataan akan diterima sebagai premis dalam argumentasi ilmiah jika telah melampaui pengkajian secara ontologik .ilmu berdasarkan landasan ontologik berarti mendasarkan diri pada kenyataan diri pada kenyataan sebagaimana adanya dapat membantu dalam menjelaskan,meramalkan dan mengontrol gejalah yang ada untuk menuju keciri-ciri substansial dari alam (objek ilmu pengetahuan). 


\section{Jeuken memberi suatu suatu hukum yang sungguh-sungguh} pengertian ontologi ilmu sebagai mengungkapkan ciri essensial dari alam berikut. sebagaimana alam tersebut tampil).

"on the level of science there is close contact with observation on experiment. Scientists try to enunciate a more general law deeper insight into them. Such a law is found by way of induction, which process in typical for the level. The result is not a law which only would indicate what is most occurring in nature, but a law indeed expresses an essential feature of nature-as it appears" (Jeuken, 1958, hal. 140)

(Pada level ilmu ada suatu hubungan erat dengan observasi dan eksperimen. Para ilmuwan mencoba menyatakan suatu hukum yang lebih umum tentang fenomena agar supaya mendapatkan suatu pengertian yang lebih dalam tentang fenoomena tersebut. Hukum yang demikian itu diperoleh melalui induksi, yang prosesnya khas bagi level ini, hasilnya bukan suatu hukum yang hanya menunjuk apa yang betul-betul terjadi dalam alam, tetapi

Pertama, mengambil dari postulat, yaitu kebenaran-kebenaran apriori, yaitu dalil yang dianggap benar walaupun kebenarannnya tidak dibuktikan, kebenarannya yang sudah diterima sebelumnya secara mutlak, kedua, mengambil dari teori sarjana/ahli yang lain terdahulu, yang 
kebenaraannya tidak disangsikan lagi oleh masyarakat, terutama oleh sipenyelidik itu sendiru. (Endang Saifuddin Anshari, 1987).

Mengenai asumsi dasar dalam keilmuan, Harsojo menyebutkan tentang macamnya:

\section{Dunia itu ada, dan kita dapat mengetahui bahwa dunia itu} benar ada.

Apakah benara dunia ada?

Pertanyaan itu bukanlah pertanyaan ilmiah melainkan pertanyaan filsafat. Oleh karena itu ilmu yang kita pelajari itu adalah ilmu pengetahuan empiris, maka landasannya adalah dunia empiris itu sendiri, yang eksistensinya tidak diragukan lagi. "dunia itu ada" diterima oleh ilmu dengan begitu saja, dengan apriori atau dengan kepercayaan. Setelah ilmu menerima kebenaran eksistensi dunia empiriss itu, barulah ilmu mengajukan pertanyaan-pertanyaan lebih lanjut, seperti misalnya : 'Bagaimanakah dunia empiris alam dan sosial itu tersusun'.

\section{Dunia empiris itu dapat diketahui oleh manusia oleh manusian melalui pancaindera}

Mungkin ada jalan-jalan lain untuk mendapatkan pengetahuan mengenai dunia empiris itu,akan tetapi bagi ilmu satu-satunya jalan untuk mengetahui fakta ilmiah adalah melalui pancaindera. Adanya penyempurnaan terhadap pancaindera manusia dengan membuat alat-alat ekstension yang lebih halus ... tidak menguragi kenyataan bahwa pengetahuan tentang dunia empiris itu diperoleh 
melalui pancaindera. Ilmu bersandar kepada kemampuan pancaindera manusia beserta alat-alat ekstensionnya.

\section{Fenomena-fenomena}

yang terdapat didunia

\section{berhubungan satu sama lain} secara kausal.

Berdasarkan atas postulat bahwa fenomena-fenomena di dunia itu saling berhubungan secara kausal, maka ilmu mencoba untuk mencari dan menemukan sistem,struktur, organisasi, polapola dan kaidah-kaidah di belakang fenomena-fenomena itu dengan jalan menggunakan metode ilmiahnya (Endang Saifuddin Anshari, 1987).

\section{PENUTUP}

Ontologi merupakan kawasan yang tidak termasuk ilmu yang bersifat otonom tetapi otologi berperan dalam perbincangan mengenai pengembangan ilmu, asumsi dasar ilmu, dan konsepkuensinya juga berpengaruh pada penerapan ilmu. Ontologi merupakan sarana ilmiah menemukan jalan untuk menangani suatu masalah secara ilmuan. Ontologi mendahuluhi ilmu dan bukan pembicaraan dalam ilmu itu sendiri. Walaupun begitu ontologi penting bagi pengembangan ilmu. Sebagaimana telah dikemukakan, bahwa berfikir ontologis mempunyai corak kritis spekulatif, artinya pembahasan di dalam ontologi di mulai tanpa asumsi dasar, melainkan mengandalkan kreativitas akal yaitu inspirasi, intuisi, dan ilham. Metode abstraksi digunakan ontologi untuk mencari kejelasaan tentang dunia fakta seluruhnya sampai pada pengertian fundamental. Pengetahuan fundamental yang dihasilkan oleh ontologi dapat dijadikan dasar untuk membahas 
kembali asumsi dasar yang oleh ilmu pengetahuan telah dianggap mapan kebenarannya. Dalam persoalan pengembangan ilmu pengetahuan ini van Peursen mengatakan : bahwa tidak ada ilmu yang selesai, para ilmuwan selalu dapat mengembangkan ilmunya lebih lanjut. Ilmu bukan ibarat sebuah rumah dengan dasar abadi sepanjang sejarah hanya dilengkapi dengan tingkat-tingkat baru. Struktur ilmu bahkan pokok-pokok ilmu mengalami perubahan. Ontologi menyelidiki dasardasar ilmu. Penelaahan ontologi dapat dijadikan dasar merumuskan hipotesishipotesis baru untuk memperbaharui asumsi-asumsi dasar yang pernah digunakan.

\section{DAFTAR PUSTAKA}
Bahm,A.J., 1986, Metaphysics, Harper And Row New Mexico: Publishers,

Bakker, A, 1992, Ontologi : Metafisika Umum, Yogyakarta: Kanisius
Barnett, L, 1991, The Universe And Dr. Einstein, Semarang: Dahara Priza

Daoed Yoesoef, 1986, Pancasila, Kebudayaan Dan Ilmu Pengetahuan, Panitia Seminar Pancasila Sebagai Orientasi Pengembangan Ilmu, Yogyakarta

Endang Saifuddin Anshari, 1987, Ilmu Filsafat Dan Agama. Surabaya: , Bina Ilmu

Hawking, S., 1994, A Brief History Of Time, Terjemahan: A. Hadyana $P$. Jakarta: Pustaka Utama Grafiti

Huwaidi, H., 1983, Al-Wujud AlHaq/Ontology, Terjemahan: Syarqowi Dhofier. Yogyakarta:, Hanindita,

Kaatsoff,L.O., 1986, Elements Of Philosophy, Terjemahan: Soejono S., Yogyakarta: Tiara Wacana

Lorens Bagus, 1991, Metafisika, , Jakarta: P. T. Gramedia

Notonagoro,1975, Pancasila Secara Ilmiah Populer, Jakarta: Pancuran Tujuh

Soejono Soemargono,1983, Filsafat Ilmu Pengetahuan, Yogyakarta: Nur Cahaya

Soeroso M, Prawirohardjo,1983, Pidato Pengukuhan Guru Besar; Peranan Meta Etik Di Balik 
Jurnal Tarbawi| Volume 4|No 1| p-ISSN : 2527-4082, e-ISSN : 2622-920X 99

Kebijaksanaan

Pengetahuan,

Gama Press

The Liang Gie, 1984, Konsepsi Tentang Teknologi, Yogyakarta: Yayasan Studi Ilmu Dan Teknologi,

Van Peursen, C. A., 1985, De Opbouw Van Ce Weteschap Een Inleiding In De Wetenschapleer;
Susunan Ilmu Pengetahuan, Alih Bahasa J. Drost, Jakarta: Gramedia

Yeuken, M. SJ, 1968, Philosophy And Theoretical Science, Majelis Ilmu Pengetahuan Indonesia,Jakarta

Yuyun S. Suriasumantri, 1991, Ilmu Dalam Perspektif, Jakarta: Gramedia 